\title{
POSTCOLONIAL TENDENCIES IN TRANSLATION IN THE LIGHT OF CENTRE-PERIPHERY PRE-CONCEPTUAL IMAGE SCHEMA
}

\author{
PATRYCJA KARPIŃSKA \\ Institute of English Studies, Faculty of Letters, \\ University of Wrocław, \\ ul. Kuźnicza 22, Wrocław, Poland \\ E-mail address: patrycja.karpinska@uwr.edu.p1
}

\begin{abstract}
One of the main characteristics of translation is that it can be called everything but stable; multiple cultural, social, political, and economic processes are reflected in translation. Postcolonial studies in translation deal with, among others, cultural and linguistic hegemonies as well as strong and weak - or central and peripheral cultures and the relations between them. Many of the theories (Even-Zohar, 1979; Tymoczko, 1999) state that strong cultures set an example whereas weak cultures attempt at following this example, even at the cost of their own values and culture (so-called foreignization in translation). It is significant to ask oneself why such processes take place. The investigation of the pre-conceptual image schemata of CENTRE-PERIPHERY and PLUS-MINUS polarity of the SCALE sheds some light on the nature of these interactions (Krzeszowski, 1997).

Key words: postcolonialism, foreignization, domestication, pre-conceptual image schemata, centre, peripheries
\end{abstract}

\section{INTRODUCTION}

Susan Bassnett and Harish Trivedi write that "[translation] rarely, if ever, involves a relationship of equality between texts, authors or systems" (1999, p. 2). In modern world, just as the topic of inequality between people is one of the thorniest issues for governments and politicians, the topic of inequality between cultures is one heavily explored by numerous scholars. The fact that certain cultures are valued higher than the others carries significant consequences. As Stuart Hall notices, this cultural hegemony " provides criteria of evaluation against which other societies are ranked and around which powerful positive and negative feelings cluster" (2000, p. 186 [1996]). These relations of power are also reflected in translation and they are investigated by a number of postcolonial theories. It seems that the hierarchical structure of cultures and languages is one of the main constituents of a translator's 
approach towards the text. The second part of the article starts with a discussion on the foreignization/domestication dichotomy, which is of the utmost relevance for us as it describes the precise nature of processes investigated within the postcolonial theories. Two of the foreignization/domestication theories are discussed, namely the oldest - Schleiermacher's theory (2006 [1813]) - and the most recent (and controversial) one, proposed by Lawrence Venuti (1995). At the end of the article, the psycho-cognitive background is provided. The analysis of the centre-periphery schema (Krzeszowski 1997) hopefully sheds light onto the issue as to why these two concepts are of such significance to us.

To sum up, the article attempts at answering the following questions: what is the subject of interest for the postcolonial scientists working within the field of Translation Studies? How could we describe the relationship between central and peripherial cultures? How is it displayed in translation and what is its exact nature? And finally, is there any cognitive background explaining those processes?

\section{POSTCOLONIAL THEORIES IN TRANSLATION STUDIES}

Theoretically, the relationship between the former colonies and their masters is the subject of interest of postcolonial theories. However, a significant number of scholars propose wider understanding of the term 'colony'. Hall distinguishes between the West and 'the West', the former being a geographical West of Europe, while the latter being "as much an idea as a fact of geography" (2000, p. 185) and applying to the modern dominant cultures. However, the notion of 'the West' can be even more deceiving as "Eastern Europe doesn't ... belong properly to 'the West' whereas the United States, which is not in Europe, definitely does" (Hall, 2000, p. 185). Thus, perhaps the best solution is to abandon the discourse of colonies and their masters as well as 'the West and the Rest', and apply such notions as centre and peripheries. These are the terms proposed by Immanuel Wallerstein - by the term 'centre,' Wallerstein understands military and economic powers, while the countries that were colonized or that are currently exploited by the centre are called 'peripheries' (after Turner 2004, p. 259). The terminology of centre and peripheries is also preferred by Itamar Even-Zohar, a scholar from Tel-Aviv School, who created the theory of polysystems that applies strictly to translation and, thus, is in the centre of our attention.

According to Even-Zohar, literature does not function in a void but it highly depends on its cultural, social, and political environment. The literature, or rather literatures, constitutes an enormous polysystem, i.e. a system comprised of numerous other, smaller systems. Those systems interact with each other on the global but also national scale and they fight to assume certain positions within the polysystem (Munday 2004, p. 109). Translated works are part of the polysystem as well as national pieces of literature and 
they can assume in a literary system one of two positions - peripherial or central. The position of translation is not given once and for all but depends on the relations present in the culture (Even-Zohar, 2009, p. 203). Even-Zohar claims that if translated literature takes peripherial position, it has no influence over the centre of polysystem. It only uses the models that are already present and it reflects the values that are characteristic of the target culture (2009, p. 200). However, if translated literature assumes a central position in the polysystem, then it takes part in the formation of the model, e.g. new literary models are introduced through translation (2009, p. 198). The scholar lists three situations in which translation can be in the centre: when the polysystem is not yet completely formed; when national literature is peripherial or weak; or when a certain crisis takes place (2009, p. 199).

Even-Zohar observes that in the countries that used to be colonizers, the national literature assumes the central position in the polysystem, while the 'colonial' literature is in the peripheries (2009, p. 200). The position of literatures in polysystems is particularly interesting as it appears to reflect relations of power between economical and cultural centres and peripheries. If the culture belongs to the centre, then its national literature is highly valued and, analogically, is in the centre of polysystem; the literature written in the peripheries takes peripherial position. However, if the culture belongs to the peripheries, then the translated literature that is transferred from the centre should assume central position in this foreign polysystem as well, for the transferred is valued higher than national. The countries from peripheries 'consume' the culture of the centre and act upon it.

The position of translated literature in the polysystem influences the translator's decisions. When translation takes a peripherial position, translators use already existing models (Even-Zohar, 2009, p. 200); they apply domesticating techniques (so-called domestication of the text). Maria Tymoczko notices that a post-colonial ${ }^{1}$ author who writes a text for the international public or dominating, central culture is forced to simplify his or her culture. Such author performs an act of domestication on his or her culture in order to make it more available for the readers from the centre; the author explains foreign notions or even substitutes them with the elements of target culture (Tymoczko, 2009, pp. 434-437). Prestigious authors are an exception in this case - if they are well-known and respected, they can 'demand' more from their readers (2009, p. 441). Tymoczko provides an example of Ngugi Wa Thiong'o who - as he became famous - was leaving more and more foreign words or even phrases without an explanation and, thereby, was setting higher standards for his readers (2009, p. 444). If the situation is reversed and translation assumes central position, then even quasi- and semi- translations belong to the category of translated literature. The translation is more adequate and 'closer' to the original text as the translator decides to apply foreignizing rather than domesticating techniques (so-called foreignization). Furthermore, Tymoczko also observes that the translator who renders a

1 Or peripherial, as Tymoczko includes under this term also literature of minority groups. 
text written in the centre into the language of peripheries is more likely to leave cultural elements in the text without providing any explanation for the reader $(2009$, p. 439).

To sum up, it can be ironically said that the peripheries are now in the centre of attention. However, this fascination with postcolonialism did not change the relations of power. Bassnett and Trivedi sum up their article by stating that "the old business of translation as traffic between languages still goes on in the once-and-still colonized world, reflecting more accurately than ever before the asymmetrical power relationship between the various local 'vernaculars' (i.e. the languages of slaves, etymologically speaking) and the one master-language of our post-colonial world, English" (Bassnett \& Trivedi, 1999, p. 13). We established how translation is affected by relations of power; we will move on now to explore the aforementioned notions of foreignization and domestication to deepen our understanding of the processes that take place in translation.

\section{FOREIGNIZATION AND DOMESTICATION}

The dichotomy of foreignization and domestication is a concept that is not only brought up in numerous discussions concerning translation but also controversial. Translation theoreticians were interested in it for centuries; yet, the first scholar to define it as it is understood nowadays was Frederick Schleiermacher in his essay On the different methods in translating in 1813. Even though he formulated his theory over 200 years ago, his views and his famous metaphor of translation as a journey are still applicable and quoted by numerous other scholars (e.g. Tabakowska, 2009; Venuti, 1995). Certainly, some of the assumptions were revised, yet the main idea of his work survived. Lawrence Venuti is the author of the most modern approach towards foreignization and domestication, and the one who coined these terms. Though his theory might not be as widespread as Schleiermacher's and might have faced a considerable amount of critique (e.g. Hejwowski, 2004), it is worth attention as Venuti formulates his views in the context of Anglo-American domination.

Let us begin with the older of the two theories. Already in 1813, Schleiermacher pinpoints that communication in translation is not a simple and straightforward task. He notices that perfect equivalents are nearly non-existent; grammar, lexis and syntax vary from language to language and they are not complementary (2006, p. 45). Yet in the area of artistic, literary and scientific translation, the translator's task is to construe a target language text that displays both linguistic and mental virtues of the source language text's author. Otherwise, the translator is said to fail this task and readers are deprived thereof. To make translation even a more complicated undertaking, Schleiermacher notices that "all he [translator] can offer them [readers] as a help for achieving these two things [virtues] is their own language, corre- 
sponding in none of its parts to the other tongue" (2006, p. 47). Schleiermacher feels that the translator facing these issues can take one of two paths - "[e]ither the translator leaves the author in peace as much as possible and moves the reader toward him; or he leaves the reader in peace as much as possible and moves the writer toward him" (2006, p. 49). However, the philosopher warns that these two choices should not be mixed. The translator should be consistent in his work and choose only one option through the whole text (2006, p. 49).

Schleiermacher states that if the translator decides to "leave the author in peace," then his or her aim is to produce such a translation that would have a similar impact on a target language reader to the one the text had on the source language readers; it is as if the author rendered the text himself or herself (2006, p. 49). The philosopher compares it also to the situation when the target language reader knows the source language well enough to read the original text freely. The process of reading should be enjoyable and the text should be comprehensible without great effort. Yet, the reader should be aware that this is not a text written in his language and culture (2006, p. 51). The translation should not be defamiliarized in a random manner, just to appear foreign. It should rather provide the reader with "an inkling, if only a distant one, of the original language and what the work owes to it" (2006, p. 54). Furthermore, the translator should also try to render in such a way that the translated text would not lose all of its connotations (2006, p. 51). Only by fulfilling these commandments can the translator take the readers on a journey to the author.

If the translator intends to bring the author to the readers, it is more a guessing game than translation; the translator attempts to imagine what a person the author would be had he or she been born in a target language country and what text he or she would write in such circumstances. The text should be fluent and easily understood; the reader should not have any suspicion about the origins of the text. In other words, the translation should appear as a text originally written in the target language. Schleiermacher comments on this method in such words - "[i]n a certain sense, it is possible for us to think of how Tacitus might have spoken had he been German, or, to be more precise, how a German would speak whose relationship to our language was the same that of Tacitus to his own" (2006, p. 56). The author reveals his stance towards this method in the very next sentence, when he comments ironically, "and happy is he who is able to imagine this so vividly that he can really make him speak!" (2006, p. 56). Hence, according to Schleiermacher, there is not much use for bringing the author to the reader (2006, p. 59). The philosopher advocates the first approach, i.e. bringing the reader to the author.

The notions of domestication and foreignization were introduced in 1995 by Lawrence Venuti. Venuti compares the process of domestication to Schleiermacher's taking the author to the reader; it is "an ethnocentric reduction of the foreign text to target-language cultural values" (1995, p. 20). Foreigniza- 
tion corresponds to Schleiermacher's taking the reader to the author and it is defined as "an ethnodeviant pressure on those values to register the linguistic and cultural difference of foreign text" (1995, p. 20).

Venuti discusses domestication in the context of current trends in the Anglo-American translation. He points out that in the modern Englishspeaking world, a translation is more likely to receive positive reviews if it pretends to be a text written within the sphere of Anglo-American culture and not a foreign one $(1995, \mathrm{p} .1)$. The translation has become so 'invisible' that nowadays critics who judge upon a translated text rarely even acknowledge that it is not an original; and if they do focus on translation, they assess it mainly on the basis of one criterion, i.e. fluency $(1995, \mathrm{p}$. 2). The analysis of a number of literary reviews indicates that the more natural, modern, and understandable the text and language, the better the translation. Therefore, a translated text is acceptable and positively reviewed when it does not display any unfamiliar qualities, i.e. it is domesticated. Translation conforms to prevalent domestic values, discourse, culture etc., to such an extent that it pretends not to be translation at all (1995, p. 17). The goal is to blur the difference between the cultures, "to bring back a cultural other as the same, the recognizable, even the familiar" (Venuti, 1995, p. 18).

Venuti discusses Graves's translation of Suetonius as an example of a domesticating text. He focuses mostly on the explicit homosexuality of Caesar, which is not present in the Latin text. Furthermore, while Suetonius's writing is rather objective, Graves's translation reveals itself as stigmatizing. This happens as Graves renders (Venuti's translations in the brackets), e.g. "prostratae regi pudicitiae" ("surrendered his modesty to the king") as "homosexual relationship" or "pudicitiae eius famam" ("his sexual reputation") as "specific charge of unnatural practices" (1995, p. 33). Closer analysis of the translation reveals that Graves translated Suetonius's text as if Suetonius was born in the modern Anglo-American culture and sympathized with the popular views on, e.g. sexuality (Venuti 1995, p. 34).

In his later work, Venuti advances his theory of domestication and foreignization and claims that translation is inevitably a domesticating process on each and every level (2004, p. 485). Dissimilarity between a source language and target language and their cultures is displayed in the translation implicitly - if it is at all. This takes place when the translator decides to defamiliarize the text; ergo it happens "through a domestic difference introduced into values and institutions at home" (2004, p. 483). The phrase "domestic difference" is crucial here. Even though defamiliarization is applied in order to introduce the foreign, it can be defined and understood only in relation to and in the context of the target language and target language culture. Hence, foreignization should not be understood as a transfer of foreign culture and language because such a process is impossible; foreign elements in a target language will be always seen and interpreted through the prism of a target language culture. Foreignization should be rather defined as defamiliarization and alienation of certain lingual and cultural patterns (Venuti, 1995, 
p. 20). Venuti refers to this translation strategy as 'resistancy'. 'Resistant' translation should not be easy reading; it should 'resist' the reader. The text should not pretend to be an original but rather signal its linguistic and cultural difference by neither being fluent nor displaying familiar cultural patterns (1995, p. 24). It is as though the reader is supposed to mentally stumble upon the reading of such a translation. An example of foreignizing translation could be Ezra Pound's texts. He deliberately introduces in his translations multiple archaisms, atypical collocations or even disrupted standard grammatical patterns of a target language in order to reflect the use and sound of a source language (1995, p. 34).

Venuti introduces also a concept of community and cultural gap in the context of foreignization and domestication. Community stands for the group of readers to whom the translation will appeal (2004, p. 491). Cultural gap is a concept corresponding to Nida's cultural distance. The translator does not translate only a text from one language to another but also from one culture to another. Eugene A. Nida lists different types of relationships between cultures and languages; there are cases when they are both closely related, when languages are not closely related but cultures display similarity and, the rarest case, when languages are related but cultures are diametrically different (2009, p. 58). As the author notices, the expectations that the translation is the easiest in case of closely related languages and cultures is illusory; many similarities are only on the surface, yet the translator is already thrown off guard and more likely to commit a mistake or create a target language product of little value (2009, p. 58). The similarity does not imply identification - cultural and linguistic systems do not match each other but are incompatible.

An example of such phenomenon can be found in our own culture. Let us consider the example of Halloween. Saying that Halloween is a popular celebration in the United States would be an understatement. Americans prepare for Halloween for months; only in 2011, they spent 7 billion dollars on preparations ${ }^{2}$. There are Halloween costumes, parties, candies, decorations, but also myths, stories, movies or even special TV series episodes. The concept of Halloween is also present in the Polish culture; however, here it is mostly criticized as showing disrespect to the dead. It is only one day away from All Saints' Day traditionally celebrated by the Polish people, which is the time of mourning and remembering the loved ones who passed away. Because of that, the concept of Halloween is seen in a completely different light in Poland; what is more, the celebration of Halloween is strongly opposed here. Therefore, there is a cultural gap between these two cultures and their view on Halloween.

Every translation needs to gain community in order to be deemed successful, however, its reception depends also on the discussed gap between cultures; if it is too wide, then the (especially foreignizing) translation may be rejected (Venuti, 2004, p. 491). Venuti discusses the issue of "bridg[ing] the

2 Retrieved April 12, 2015 from http://business.time.com/2011/09/29/now-thats-creepyamericans-will-blow-7-billion-on-halloween/ 
cultural gap" on the translation of Ungaretti's poetry by Mandelbaum into English (2004, p. 494). As the scholar notices, Ungaretti's poetry was revolutionary at that time in Italy because it was plain, simple, and straightforward. The English translation, on the other hand, contained multiple archaisms and metaphors and phrases from Victorian times. Hence, Ungaretti's poetry was inscribed in the translation discourse prevalent in the USA at that time and the text was altered in order to gain readership. Indeed, Mandelbaum's translation became even canonical (Venuti, 2004, pp. 492-494).

The need to rewrite Ungaretti's poetry so that it could be critically acclaimed is another sign of the Anglo-American 'resistance' to the foreign. Venuti describes the relationship of Anglo-American culture with the rest of the world as "imperialistic abroad and xenophobic at home" (1995, p. 17). While the Anglo-American part of the world rewrites all the foreign in the texts to fit it into their domestic discourse, it dominates at the same time and forces its language, culture, and values upon the rest of the world. Hence the translation imbalance described also by such scholars as Even-Zohar (2009) or Tymoczko (2009) and displayed in the application of translation procedures. However, it is worth asking oneself whether there is any psychological or cognitive motivation behind the discussed processes of domestication and foreignization in the postcolonial context? It seems that the answer is yes, there is. Let us move on now to the discussion of CENTRE-PERIPHERY pre-conceptual schema.

\section{PSYCHO-COGNITIVE BACKGROUND}

The CENTRE-PERIPHERY ${ }^{3}$ pre-conceptual image schema combined with PLUS-MINUS polarity of SCALE schema may explain the foreignization and domestication trends in the postcolonial translation and provide insights of its working mechanisms. Firstly, let us investigate the very notion of pre-conceptual image schemata.

According to Mark Johnson, pre-conceptual image schemata underlie "human bodily movement, manipulation of objects, and perceptual interactions" (1987, p. xxxvi). They arrange our view of the world and our experience. Hence, the pre-conceptual image schemata are very peculiar as at the same time they systematize our experience and they are realized on daily basis in actions that, among others, constitute this experience (Krzeszowski, 1997, pp. 108-109). Yet, pre-conceptual image schemata perform also a crucial role in our understanding; they allow us to grasp abstract notions "by metaphorical projections from the domain of physical to abstract domains" (Lakoff, 1987, p. 268; after Krzeszowski, 1997, p. 109).

Krzeszowski notices that pre-conceptual image schemata may involve multiple different experiences and, ergo, introduces differentiation into primary and secondary experience $(1997$, p. 111). Primary experience is the

3 Convention after Krzeszowski. 
one that involves our body; secondary experience includes situations connected with our culture, social life etc. The influence thereof may be traced in the language. The values inscribed in the pre-conceptual image schemata "arise from axiologically enhanced pre-conceptual image schemata in which the axiological parameter is motivated by our bodily experience [primary experience] and reinforced by various social and cultural experiences [secondary experience]" (Krzeszowski, 1997, p. 111). For example, PLUS-MINUS polarity on the SCALE schema stands for the value, where PLUS is associated with the positive values and MINUS with the negative ones (Krzeszowski, 1997, pp. 110-111). There is no truly neutral position on the SCALE; each one of them is inscribed with either positive or negative values and the reading of the position on the SCALE is not objective (Krzeszowski, 1997, p. 110). What is peculiar about the PLUS-MINUS polarity on the SCALE schema is that the schema gains meaning only once combined with another pre-conceptual image schema. Moreover, "it is from the SCALE schema that the very concept <value> arises" (Krzeszowski, 1997, p. 110).

The CENTRE-PERIPHERY schema is another pre-conceptual schema and, thus, rooted in our bodily experience. It is a result of the fact that certain body parts "are central while others are increasingly peripherial" (Krzeszowski, 1997, p. 121). The application of the SCALE schema to the CENTRE-PERIPHERY schema produces the schema in which PLUS and positive values are associated with the CENTRE, and MINUS and negative values with the PERIPHERY. Such an association, again, is rooted in our primary experience. Krzeszowski compares "cutting-off fingernails" to "cutting-off one's head" (1997, p. 121). Fingernails are extremely peripherial and cutting them off does no harm to the body; quite the opposite, as with cut-off fingernails the risk of scratching oneself is reduced. However, living without a head, both literally and metaphorically, is a tough thing to do.

Such an axiology is also reflected in our secondary experience. For instance, when a child celebrates birthday at school, he or she stands in the centre of classroom, listening to the wishes of classmates. This is to show the child that he or she is the most important person on this day. Yet, if a child misbehaves in class, he or she is sent to the corner of the classroom; the child is sent to the peripheries of the classroom as a punishment for doing wrong. People tend to place important persons and objects in the centre and unimportant or even shameful in the peripheries. Other examples are the placement of the throne or the judge in the court, as well as putting dirty clothes in the laundry basket or hiding unwanted gifts in the back of the cupboard.

The CENTRE-PERIPHERY schema is also reflected in the language. Krzeszowski offers such examples as "he occupies the central position of our cultural life," "the center of interest," "the political and cultural center," "the heart of the matter" but also "social margin," or "their activities are of marginal importance" (1997, pp. 122-123). These expressions confirm the assumptions 
made about the nature of CENTRE-PERIPHERY schema and PLUS-MINUS polarity on the SCALE schema.

These two pre-conceptual image schemata seem to explain the behaviour of translators in the postcolonial context. If we imagine a world literature polysystem as a sphere similar to the one presented below by Krzeszowski and place the Anglo-American culture part of the world in the centre, we see that this part is associated with the most positive values, while others are increasingly peripherial and negative. Therefore, it appears logical and understandable that translators from the centre domesticate (inscribe positive values) the texts coming from the peripheries (full of negative values). It explains also the behaviour of translators functioning in the peripheries; by foreignizing texts, they maintain positive values instead of replacing them with negative ones.

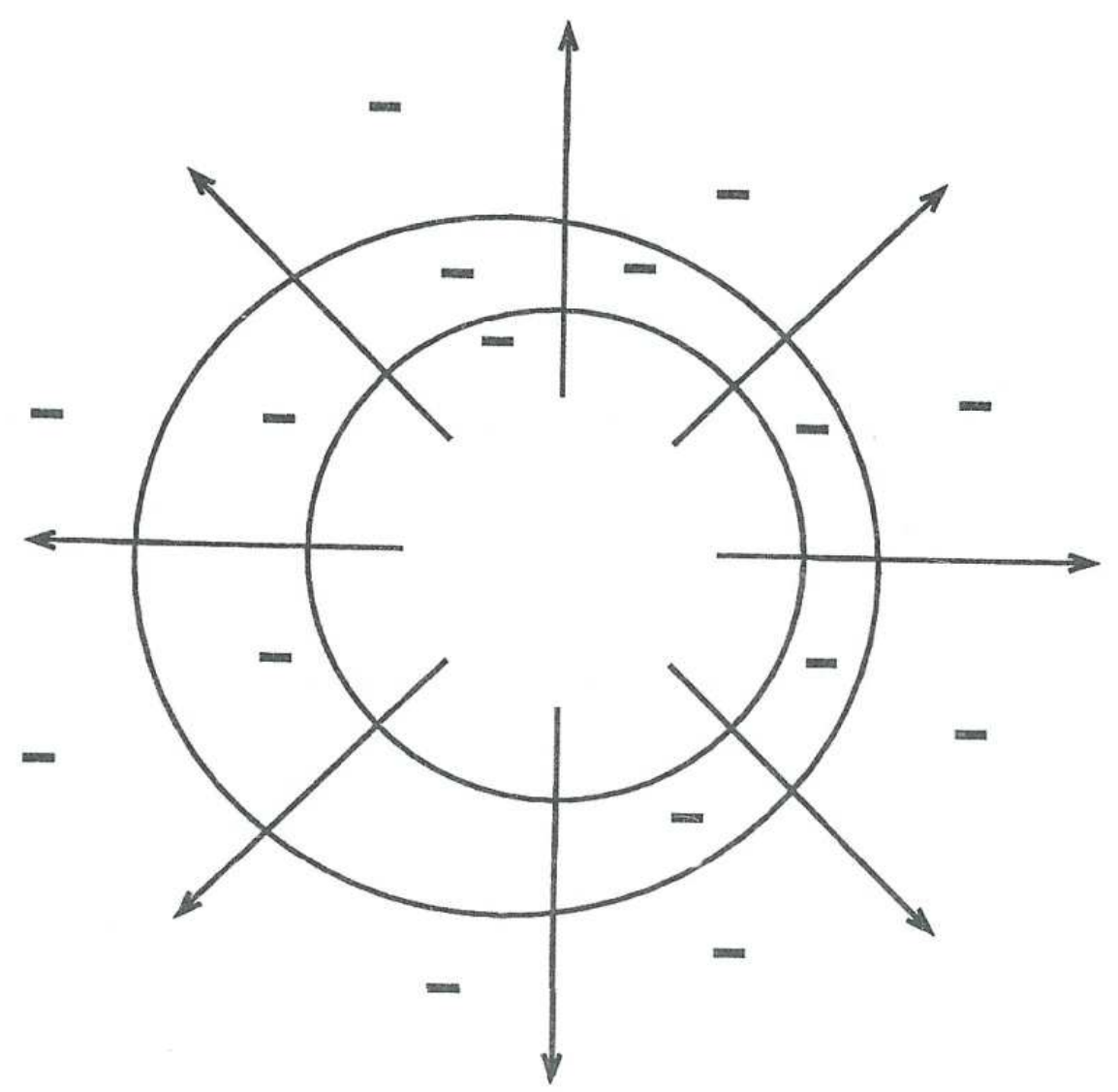

Figure 1. CENTRE-PERIPHERY schema combined with PLUS-MINUS polarity on SCALE schema (retrieved from Krzeszowski, 1997, p. 122)

Additionally, this may also provide an explanation to the creation of semi- and quasi-translations in the peripheries. These texts simply attempt to display positive and acceptable values and, hence, mimic the texts from the centre. 


\section{CONCLUSION}

Since translation is one of the predominant channels of communication, not only does it display the unequal power relations between languages and cultures but also serves their reinforcement. These issues are thoroughly investigated by the postcolonial studies, with one of the central claims that postcolonial and 'weak' countries have peripheral cultures. Consequently, former colonies and weak countries 'import' more culture and language from the central cultures (usually their former colonisers) than 'export' thereto. This trend is said to be also visible on the level of a text as translators from the peripheral cultures are more willing to apply foreignizing techniques in translation than domesticating ones. It seems that the notion of foreignization and domestication is strictly connected with the cultural hegemonies and postcolonial translation; the power relations and the positions of cultures in the polysystem determine how far the translator can proceed with foreignization or domestication in the translation until it becomes unacceptable. This acceptability can be further explained by the CENTRE-PERIPHERY schema combined with PLUS-MINUS polarity on the SCALE schema; the CENTRE is associated with positive values and PERIPHERY with negative ones.

In his article titled Des Tours de Babel, Jacques Derrida claims that universal language would be an act of colonial violence and that God, when He confounded languages, stopped "the colonial violence or the linguistic imperialism" (1985, p. 226). Yet, the question is, did God really stop linguistic imperialism when he confounded languages? Or maybe He just created lieges to serve the linguistic dictators? The analysis of the aforementioned pre-conceptual image schema suggests that it is the latter which is the case; and that the cultural centres govern not only our language but also our mind.

\section{REFERENCES}

[1] Bassnett, S. (1991). Translation Studies. London: Routledge.

[2] Bassnett, S., \& Trivedi, H. (1999). Introduction: of colonies, cannibals and vernaculars. In: S. Bassnett, \& H. Trivedi (Eds.), Postcolonial Translation: Theory and Practice (pp. 1-18). London: Routledge.

[3] Derrida, J. (1985). Des tours de Babel. Translated by J. F. Graham. Retrieved January 1, 2015, from: http://isites.-harvard.edu/fs/docs/icb.topic84298.files/Supplementary_readings/ DERRIDA.PDF.

[4] Even-Zohar, I. (2009). Miejsce literatury tłumaczonej w polisystemie literackim [The position of the translated literature within the literary polysystem]. Translated by M. Heydel. In: P. Bukowski, \& M. Heydel (Eds.), Wspótczesne teorie przektadu. Antologia [Modern translation theories] (pp. 195-204). Kraków: Wydawnictwo Znak.

[5] Hall, S. (2000). The West and the Rest: Discourse and power. In: S. Hall, D. Held, D. Hubert, \& K. Thompson (Eds.), Modernity: An Introduction to Modern Societies (pp. 184-228). Massachusetts: Blackwell.

[6] Hejwowski, K. (2004). Translation: A Cognitive-communicative Approach. Olecko: Wydawnictwo Wszechnicy Mazurskiej.

[7] Krzeszowski, T. P. (1997). Angels and Devils in Hell. Warszawa: Wydawnictwo Energeia, 108-131. 
[8] Munday, J. (2004). Introducing Translation Studies: Theories and Applications. London: Routledge.

[9] Nida, E. A. (2009) Zasady odpowiedniości [Principles of Correspondence]. Translated by Anna Skucińska. In: P. Bukowski, \& M. Heydel (Eds.), Wspótczesne teorie przekładu. Antologia [Modern translation theories] (pp. 51-71). Kraków: Wydawnictwo Znak.

[10] Schleiermacher, F. (2006). On the different methods of translating. Translated by S. Bernofsky. In: L. Venuti (Ed.), The Translation Study Reader (pp. 43-63). London: Routledge.

[11] Tabakowska, E. (2009). Ttumaczac się z ttumaczenia [Explaining oneself from the translation]. Kraków: Społeczny Instytut Wydawniczy Znak.

[12] Turner, J. H. (2004) Struktura teorii socjologicznej [The Structure of Sociological Theory]. Translated by A. Manterys et al. Warsaw: Wydawnictwo Naukowe PWN, 258-263.

[13] Tymoczko, M. (2009). Literatura postkolonialna i przekład literacki [Post-colonial writing and literary translation]. Translated by A. Sadza. In: P. Bukowski, \& M. Heydel (Eds.), Wspótczesne teorie przekładu. Antologia [Modern translation theories] (pp. 429-448). Kraków: Wydawnictwo Znak.

[14] Venuti, L. (1995). The translator's invisibility. A history of translation. London: Routledge.

[15] Venuti, L. (2004). Translation, Community, Utopia. In: L. Venuti (Ed.), The Translation Study Reader (pp. 483-502). London: Routledge. 